Article

\title{
Role of ball milling during Cs/X catalyst preparation and effects on catalytic performance in side-chain alkylation of toluene with methanol
}

\author{
Qijun Yu ${ }^{\text {a,b }}$, Jinzhe $\mathrm{Li}^{\mathrm{a}}$, Changcheng Wei ${ }^{\mathrm{a}, \mathrm{b}}$, Shu Zeng a,b, Shutao Xu ${ }^{\mathrm{a}}$, Zhongmin Liu ${ }^{\mathrm{a}, *}$ \\ a National Engineering Laboratory for Methanol to Olefins, Dalian National Laboratory for Clean Energy, Dalian Institute of Chemical Physics, \\ Chinese Academy of Sciences, Dalian 116023, Liaoning, China \\ b University of Chinese Academy of Sciences, Beijing 100049, China
}

\section{A R T I C L E I N F O}

\section{Article history:}

Received 11 November 2019

Accepted 27 December 2019

Published 5 August 2020

\section{Keywords:}

$\mathrm{X}$ zeolite

Ball milling

Ion exchange

Toluene

Methanol

Side-chain alkylation

\begin{abstract}
A B S T R A C T
Ball milling modification was performed on Cs/X catalysts before or after cesium ion exchange. Multiple characterization results (such as pyridine-FTIR, XPS, and solid-state NMR) demonstrated that ball milling played a distinct role in these two different preparation procedures of the catalyst. Ball milling performed after the cesium modification has a strong influence on the Cs/X structure and acid-base properties, which results in the enhancement of the catalytic performance for side-chain methylation of toluene with methanol. Detailed studies revealed that ball milling intensified the interactions between oxides and molecular sieves, which not only increased the dispersion of the Cs species but also generated some weaker basic centers. It is proposed that the new basic centers could be $\mathrm{Si}-\mathrm{O}-\mathrm{Cs}$ and $\mathrm{Al}-\mathrm{O}-\mathrm{Cs}$, which are produced by breaking of the $\mathrm{Si}-\mathrm{O}-\mathrm{Al}$ bonds of the zeolite framework under the synergetic effect of ball milling and alkali treatment. These new active sites may help to promote the side-chain methylation reaction. However, excessive ball milling will lead to the vanishing of zeolite micropores, thus deactivating side-chain methylation activity, which indicates that microporosity plays a key role in side-chain methylation and individual basic centers cannot catalyze this reaction.
\end{abstract}

(C) 2020, Dalian Institute of Chemical Physics, Chinese Academy of Sciences. Published by Elsevier B.V. All rights reserved.

\section{Introduction}

Styrene is the precursor to polystyrene and several copolymers and is industrially produced through ethylbenzene dehydrogenation. Ethylbenzene is commercially manufactured by alkylation of benzene with ethylene. Alternatively, styrene/ethylbenzene can be produced through side-chain methylation of toluene with methanol, which is cheaper than ethene, which is used in conventional process. In 1967 it was first reported [1] that $\mathrm{K}$ and $\mathrm{Rb}$ ion-exchanged $\mathrm{X}$ and $\mathrm{Y}$ zeolites could be applied as catalysts for this reaction. Soon afterwards, cesium ion-exchanged zeolite $\mathrm{X}(\mathrm{CsX})$ was reported to be more active [2].

Since then, CsX has been investigated intensively as an effective base catalyst for this reaction; meanwhile, various modifications on CsX were made to enhance the activity of the catalysts. It has been demonstrated that the loading capacity, location, and occupancy status of the Cs species are important for the alkylation reaction [3-5]. Moreover, the synergetic effect between acidic and basic sites is also important for this reac-

\footnotetext{
* Corresponding author. Tel/Fax: +86-411-84379998; E-mail: liuzm@dicp.ac.cn

This work was supported by the National Natural Science Foundation of China (21576256) for the financial support.

DOI: 10.1016/S1872-2067(20)63567-7 | http://www.sciencedirect.com/science/journal/18722067 | Chin. J. Catal., Vol. 41, No. 8, August 2020
} 
tion. The acidic sites were believed to stabilize the adsorbed toluene species, and basic sites were responsible for polarizing the methyl $\mathrm{C}-\mathrm{H}$ bonds of toluene and activating methanol to methyl aldehyde [6,7]. Investigations into the reaction mechanism have revealed that styrene is the initial product via side-chain methylation of toluene with methyl aldehyde. Ethylbenzene is generated by a hydrogen transfer reaction between styrene and methanol, and the concurrently formed formaldehyde in turn catalyzes the side-chain alkylation reaction [8]. Han et al. found that the side-chain methylation reactivity would be promoted by further modifying basic zeolite $\mathrm{X}$ with alkali metal oxides and suggested that formaldehyde, which is recognized as the true alkylating agent, could be generated from methanol dehydrogenation on these introduced alkali oxide particles [9].

In addition, it has been reported that ball-milled zeolite $\mathrm{KNaX}$ improved the selectivity to styrene and ethylbenzene in the methylation of toluene with methanol owing to the decrease in the Brönsted acidic site density [10]. Generally, ball milling is used to reduce the zeolite crystal size. This physical method has been applied to prepare nanosized zeolite A, ZSM-5, SAPO-34, and zeolite X [11-15]. During ball milling, larger zeolite particles could be broken into crystalline fines and partially damaged to produce the amorphous phase. Moreover, ball milling can reinforce the interaction between the supported materials and carriers, thus facilitating surface dispersion, which may lead to distinct acidic-basic site distribution and subsequent catalytic performances.

In the present work, ball milling is employed to modify a CsX catalyst in a different manner (shown in Fig. 1) to reveal the effect of ball milling on zeolite. It is demonstrated that ball milling after alkali treatment redisperses the Cs species and results in the change in the basicity of catalyst, which significantly improves the side-chain methylation activity. Based on detailed studies, a mechanism is proposed for the CsX modification during ball milling to explain this synergetic effect plausibly.

\section{Experimental}

\subsection{Catalyst preparation}

CsX catalysts were prepared by ion exchange of $\mathrm{NaX}$ (from Nankai Catalysts; $\mathrm{Si} / \mathrm{Al}=1.18, \mathrm{Na}$ content: 12.03 wt\%). The detailed preparation steps are as follows. $\mathrm{NaX}(30 \mathrm{~g})$ was treated at $80{ }^{\circ} \mathrm{C}$ for $2 \mathrm{~h}$ in a $0.4 \mathrm{~mol} / \mathrm{L}$ solution of cesium hydroxide (liquid/solid ratio: $5 \mathrm{~mL} / \mathrm{g}$ ). The slurries were centrifuged and washed with excess deionized water. Then, this procedure was repeated once more. The materials obtained were dried at $100^{\circ} \mathrm{C}$ overnight and calcined in air at $540{ }^{\circ} \mathrm{C}$ for $3 \mathrm{~h}$.

$\mathrm{Cs} / \mathrm{mill}-\mathrm{X}$ was produced by $\mathrm{Cs}$ ion exchange of the milled
$\mathrm{NaX}$ zeolite. Twenty grams of $\mathrm{NaX}$ was milled for $30 \mathrm{~min}$ at 500 rpm using a QM-3SP2 Planetary ball milling instrument. The agate balls (with diameters of 3,6, and $10 \mathrm{~mm}$ ) filled half of the agate jar. After milling, the powder of the milled zeolites was collected. Then, Cs ion exchange was performed by the following procedure: milled $\mathrm{NaX}(10 \mathrm{~g})$ was exchanged twice at $80^{\circ} \mathrm{C}$ for $2 \mathrm{~h}$ with a $0.4 \mathrm{~mol} / \mathrm{L}$ solution of cesium hydroxide (liquid/solid ratio: $5 \mathrm{~mL} / \mathrm{g}$ ). After each exchange process, the solid product was separated by centrifuging and washed with excess deionized water. The obtained materials were dried overnight at $100{ }^{\circ} \mathrm{C}$ and calcined at $540{ }^{\circ} \mathrm{C}$ for $3 \mathrm{~h}$ in air.

CsX-mill was prepared by milling the calcined CsX sample in a ball milling instrument at $500 \mathrm{rpm}$ for $30 \mathrm{~min}$.

For comparison, a sample named $\mathrm{CsX}-\mathrm{H}$, which contained a higher Cs weight fraction (Cs content: $38.83 \mathrm{wt} \%$ ), was processed in a ball milling instrument at $500 \mathrm{rpm}$ for $5 \mathrm{~h}$. Then, the powder of the milled zeolites was collected. The obtained sample was marked as CsX-H-mill-5h.

$\mathrm{CsNO}_{3} / \mathrm{ASA}$ was prepared by impregnating amorphous silica alumina (ASA) with an aqueous solution of cesium nitrate. The cesium loading was similar to that of $\mathrm{CsX}$.

$\mathrm{CsOH} / \mathrm{ASA}, \mathrm{CsOH} / \mathrm{SiO}_{2}, \mathrm{CsOH} / \mathrm{Al}_{2} \mathrm{O}_{3}$, and $\mathrm{CsOH} /\left(\mathrm{SiO}_{2}\right.$ $+\mathrm{Al}_{2} \mathrm{O}_{3}$ ) were prepared by impregnating amorphous silica alumina (ASA), silica-gel powder, $\gamma-\mathrm{Al}_{2} \mathrm{O}_{3}$, and a mixture of the silica-gel powder and $\gamma-\mathrm{Al}_{2} \mathrm{O}_{3}$ with an aqueous solution of cesium hydroxide, respectively. The weight fraction of cesium in the different samples was similar to that of CsX. These samples were designed to demonstrate the acid-base synergetic effect and the role of micropores in the reaction.

\subsection{Catalyst characterization}

Powder X-ray diffraction (XRD) patterns were recorded on a PANalytical X'Pert PRO X-ray diffractometer with $\mathrm{Cu} K_{\alpha}$ radiation $(\lambda=1.54059 \AA)$ source operating at $40 \mathrm{kV}$ and $40 \mathrm{~mA}$. The spectra were recorded from $5^{\circ}$ to $50^{\circ}$.

Scanning electron microscopy (SEM) images were examined on a Hitachi SU8020 instrument and energy-dispersive X-ray spectroscopy (EDX) was performed on the same instrument, which was operated at an acceleration voltage of $20 \mathrm{kV}$.

$\mathrm{N}_{2}$ adsorption-desorption isotherms were obtained using a Micromeritics ASAP 2020 analyzer at $-196{ }^{\circ} \mathrm{C}$. Before each experiment, the sample was degassed at $350{ }^{\circ} \mathrm{C}$ under vacuum for $4 \mathrm{~h}$. The total surface area was calculated based on the BET equation. The total pore volume was determined by the amount of nitrogen desorbed. The micropore surface area and micropore volume were assessed by the $t$-plot method.

$\mathrm{NH}_{3}$-TPD (temperature-programmed desorption) and $\mathrm{CO}_{2}$-TPD were conducted on a Micromeritics Autochem II 2920 device. The $\mathrm{NH}_{3}$-TPD experiment was conducted according to the following steps: approximately $0.2 \mathrm{~g}$ of the sample

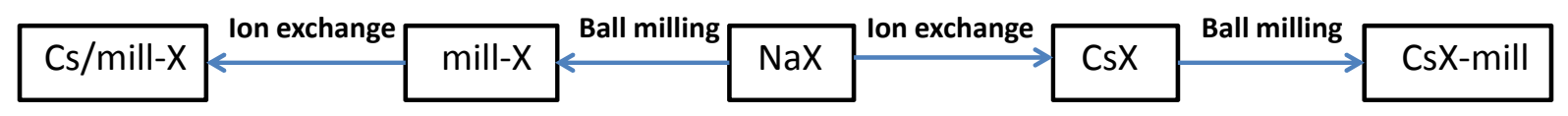

Fig. 1. The procedure of catalyst preparation. 
with particle size of $40-60$ mesh was treated for $1 \mathrm{~h}$ at $550{ }^{\circ} \mathrm{C}$ in helium, then cooled to $100{ }^{\circ} \mathrm{C}$, and subjected to a flow of $\mathrm{NH}_{3} / \mathrm{He}$ for 30 min to saturate the sample with $\mathrm{NH}_{3}$. Subsequently, the sample was purged by a helium flow for $30 \mathrm{~min}$ to remove the physically adsorbed $\mathrm{NH}_{3}$ molecules. The TPD curves were obtained at a heating rate of $10^{\circ} \mathrm{C} \mathrm{min}-1$ from 100 to $550{ }^{\circ} \mathrm{C}$. The desorbed $\mathrm{NH}_{3}$ was detected using gas chromatography with a thermal conductivity detector (TCD). The same procedure was used for the $\mathrm{CO}_{2}$-TPD experiments, but the absorption gas was pure carbon dioxide.

Pyridine adsorption FT-IR spectra were obtained with a Bruker tensor 27 instrument at a resolution of $4 \mathrm{~cm}^{-1}$. The samples were pressed into thin wafers and were then placed in an IR cell equipped with a vacuum system. The samples were pretreated under vacuum $\left(10^{-2} \mathrm{~Pa}\right)$ at $450{ }^{\circ} \mathrm{C}$ for $1 \mathrm{~h}$. Pyridine vapor flowed into the sample cell for $5 \mathrm{~min}$ when the temperature dropped to room temperature. Then, the spectra were recorded. The samples were desorbed under vacuum $\left(10^{-2} \mathrm{~Pa}\right)$ at $150{ }^{\circ} \mathrm{C}$ and $350{ }^{\circ} \mathrm{C}$. After cooling to room temperature, the corresponding spectra were recorded.

X-ray photoelectron spectroscopy (XPS) was conducted with a Thermo ESCALAB $250 \mathrm{Xi}$ spectrometer. The disk sample was irradiated by X-rays provided by a monochromatic Al $K_{\alpha}$ source $(1486.6 \mathrm{eV}, 15 \mathrm{kV}, 10.8 \mathrm{~mA})$. The binding energy (BE) values were referenced to the $\mathrm{C} 1 s$ line of the residual carbon at $284.6 \mathrm{eV}$. The surface atomic concentrations were calculated from the photoelectron peak areas of $\mathrm{Na} 1 s, \mathrm{Al} 2 s, \mathrm{Si} 2 p$, and $\mathrm{Cs}$ $3 d$. Data analysis was performed using Casa XPS software.

All solid-state NMR experiments were performed using a Varian Infinity-plus 400 spectrometer equipped with a $9.4 \mathrm{~T}$ wide-bore magnet. The resonance frequencies in this field strength were 104.2 and $79.4 \mathrm{MHz}$ for ${ }^{27} \mathrm{Al}$ and ${ }^{29} \mathrm{Si}$, respectively. A $5 \mathrm{~mm}$ MAS probe with a spinning rate of $10 \mathrm{kHz}$ was employed to acquire ${ }^{27} \mathrm{Al}$ NMR spectra. The ${ }^{27} \mathrm{Al}$ MAS NMR spectra were obtained using a single pulse sequence. Two hundred scans were accumulated with a $\pi / 12$ pulse width of $0.7 \mu$ s and a recycle delay of $2 \mathrm{~s}$. The chemical shifts were referenced to $\left(\mathrm{NH}_{4}\right) \mathrm{Al}\left(\mathrm{SO}_{4}\right)_{2} \cdot 12 \mathrm{H}_{2} \mathrm{O}$ at $\delta=-0.4$. The ${ }^{29} \mathrm{Si}$ MAS NMR spectrum was recorded with a $5 \mathrm{~mm}$ MAS probe with a spinning rate of 8 $\mathrm{kHz}$ using high-power proton decoupling. Three to four thousand scans were accumulated with a $\pi / 4$ pulse width of $2.0 \mu \mathrm{s}$ and $10 \mathrm{~s}$ recycle delay. The chemical shifts were referenced to kaolinite at $\delta=-91.5$.

\subsection{Catalytic testing}

Methylation of toluene with methanol was conducted in a vertical, fixed-bed quartz reactor at atmospheric pressure. All samples were pressed, crushed, and then sieved to 40-60 mesh. One gram of the sample was loaded onto the reaction bed and activated in situ at $500{ }^{\circ} \mathrm{C}$ under a flow of nitrogen for $1 \mathrm{~h}$; then, it was cooled to the reaction temperature, $425^{\circ} \mathrm{C}$. The flow rate of the carrier gas nitrogen was set at $10 \mathrm{~mL} \mathrm{~min}^{-1}$. After the flow rate and temperature were stabilized, a liquid mixture of toluene and methanol with a molar ratio of 1:1 was pumped steadily into the reactor at a rate of $0.038 \mathrm{~mL} \mathrm{~min}^{-1}$. The weight hourly space velocity was $2.0 \mathrm{~h}^{-1}$. The different gaseous products were analyzed by an online gas chromatography system (Agilent Technologies GC7890B) equipped with three detectors (two flame ionization detectors (FIDs) and one TCD) and three columns. A HP-PLOT/Q capillary column (length $30 \mathrm{~m}$, diameter $0.53 \mathrm{~mm}$, film thickness $40 \mu \mathrm{m}$ ) was connected to an FID that was used to analyze light components, such as methane, ethylene, ethane, methanol, and dimethyl ether. The other FID, which was equipped with an HP-FFAP capillary column (length $50 \mathrm{~m}$, diameter $0.32 \mathrm{~mm}$, film thickness $0.5 \mu \mathrm{m}$ ) was applied to analyze heavy hydrocarbons, such as toluene, ethylbenzene, styrene, and xylene. Moreover, a TCD equipped with a TDX-01 ( $2 \mathrm{~m} \times 1 / 8$ ") stainless-steel packed column was used to analyze $\mathrm{H}_{2}, \mathrm{CO}$, and $\mathrm{CO}_{2}$. Both the FIDs could detect toluene, which served as an internal standard for light and heavy hydrocarbons. Methane could also be detected by the TCD. Therefore, it was employed as an effective internal standard for $\mathrm{CO}, \mathrm{CO}_{2}$, and hydrocarbons.

The toluene conversion $\left(C_{\mathrm{T}}\right)$, the methanol conversion $\left(C_{\mathrm{M}}\right)$, the aromatic selectivity of the side-chain products $\left(S_{i}\right)$, the total yield of styrene and ethylbenzene $\left(Y_{\mathrm{ST}+\mathrm{EB}}\right)$, and the product selectivity ( $C \%)$ of the various products are defined as follows:

$$
C_{\mathrm{T}}=\Sigma y_{i, \mathrm{o}} /\left(y_{\mathrm{Tol}, \mathrm{o}}+\Sigma y_{i, \mathrm{o}}\right) \times 100 \%
$$

$C_{\mathrm{M}}=\left(\right.$ methanol $_{\text {inlet }}-$ methanol $\left._{\text {outlet }}-2 \times \mathrm{DME}_{\text {outlet }}\right) /$ methanol $_{\text {inlet }}$ $\times 100 \%$

$$
S_{i}=y_{i, 0} / \Sigma y_{i, 0} \times 100 \%
$$

$$
Y_{\mathrm{ST}+\mathrm{EB}}=C_{\mathrm{T}} \times S_{\mathrm{ST}+\mathrm{EB}}
$$

Product selectivity $(C \%)=$ target productout $/$ pproduct $_{\text {out }} \times$ $100 \%$

where $y_{\text {Tol,o }}$ and $\Sigma y_{i, 0}$ are the outlet molar fraction of toluene and the total molar fractions of the aromatic products. $\mathrm{C}_{n} \mathrm{H}_{m}$ outlet represents the moles of $\mathrm{C}_{n} \mathrm{H}_{m}$ in the outlet.

\section{Results and discussion}

\subsection{Characterization of catalyst}

\subsection{1. $X R D$}

The XRD patterns of all catalysts are shown in Fig. 2. It can be observed that all of them exhibit the characteristic peaks of the faujasite framework [16]. When NaX was ion-exchanged to CsX, the intensity of the relative diffraction peaks decreased greatly, which is consistent with previous reports $[4,17,18]$. One important reason for this phenomenon is the changes in the X-ray adsorption coefficient and in the structure factor induced by the replacement of sodium by cesium. Another reason might be the partial collapse of the zeolite framework caused by the ion exchange treatment. When CsX was converted to CsX-mill by subjecting CsX to ball milling, the peak intensity was further decreased, but the characteristic peaks of the faujasite framework persisted. This indicates that ball milling also has an effect on the structure of the zeolite, and the lattice structure of CsX survives after 30 min of ball milling. However, the peak intensity of Cs/mill-X was higher than that of CsX-mill, although both samples had undergone ball milling and ion exchange. Besides, the peak intensity of $\mathrm{Cs} /$ mill-X was comparable to that of CsX, and that of mill-X was the same as that of NaX. This suggests that the effect of ball milling on the structure 


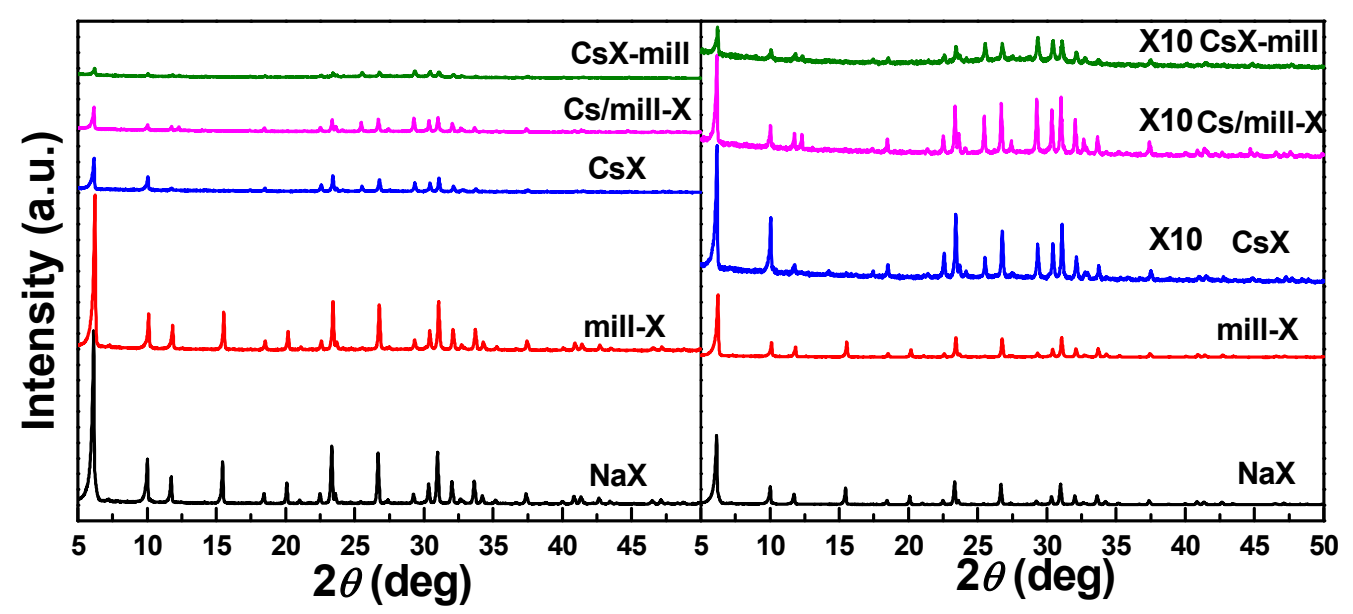

Fig. 2. XRD patterns of $\mathrm{NaX}$, mill-X, CsX, Cs/mill-X, and CsX-mill. The intensity of Cs-form zeolites is magnified ten times on the right part of the figure.
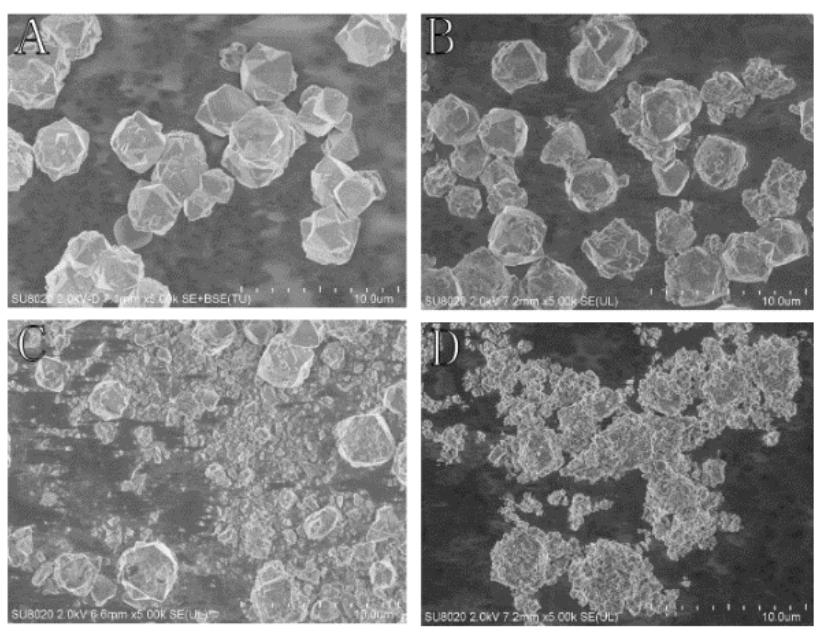

Fig. 3. SEM images of four samples: (A) NaX, (B) CsX, (C) Cs/mill-X, and (D) CsX-mill.

of $\mathrm{NaX}$ and the subsequent conversion to $\mathrm{Cs} / \mathrm{mill}-\mathrm{X}$ is non-significant. A new peak at approximately $25.6^{\circ}$ was observed for all cesium modified samples, which was assigned to the $\mathrm{Cs}_{2} \mathrm{O}$ phase (PDF No. 09-0104). The XRD pattern of CsX-H-mill-5h is shown in Fig. S1 (in SI), which suggests that the lattice structure of CsX collapsed completely after milling for a long time.

\subsubsection{SEM}

Fig. 3 shows the SEM images of four samples. An octahedron morphology can be observed in NaX with a crystal size of 2-3 $\mu \mathrm{m}$. CsX shows almost the same morphology. After milling, particles of either Cs/mill-X or CsX-mill were crushed into irregular and smaller catalyst particles. However, some differences remain between $\mathrm{Cs} /$ mill-X and CsX-mill. The particles of Cs/mill-X were only shortened to smaller crystals, whereas for CsX-mill the regular morphology disappeared, forming disordered agglomerates instead. These results are in agreement with the XRD results.

\subsection{3. $X R F$ and $N_{2}$ physical adsorption}

The physicochemical properties of the different samples are summarized in Table 1 . A slight decrease in the $\mathrm{SiO}_{2} / \mathrm{Al}_{2} \mathrm{O}_{3}$ ratio was observed for the cesium ion-exchanged samples compared to that for $\mathrm{NaX}$, which resulted from the desilication of the zeolite during the ion exchange process [19]. The alkali metal contents of CsX, Cs/mill-X, and CsX-mill in Table 1 are similar, which suggests that the milling conditions had no impact on the composition of the CsX catalysts. The nitrogen adsorption-desorption isotherms of the cesium ion-exchanged samples are displayed in Fig. S2. CsX-mill exhibits an obvious hysteresis loop, which is attributed to inter-crystal mesopores. The BET surface area $\left(A_{\mathrm{BET}}\right)$, micropore surface area $\left(A_{\text {micro }}\right)$, micropore volume $\left(V_{\text {micro }}\right)$, and total pore volume ( $\left.V_{\text {total }}\right)$ of all the

Table 1

Physicochemical properties of the samples.

\begin{tabular}{lccccccc}
\hline Catalyst & $\mathrm{SiO}_{2} / \mathrm{Al}_{2} \mathrm{O}_{3}{ }^{\mathrm{a}}$ & $\mathrm{Si} / \mathrm{Al}{ }^{\mathrm{b}}$ & $\mathrm{Cs}_{2} \mathrm{O}^{\mathrm{a}}$ & $A_{\mathrm{BET}}{ }^{\mathrm{c}}\left(\mathrm{m}^{2} / \mathrm{g}\right)$ & $A_{\text {Micro }}{ }^{\mathrm{d}}\left(\mathrm{m}^{2} / \mathrm{g}\right)$ & $V_{\text {Micro }}{ }^{\mathrm{d}}\left(\mathrm{cm}^{3} / \mathrm{g}\right)$ & $V_{\text {Total }}\left(\mathrm{cm}^{3} / \mathrm{g}\right)$ \\
\hline $\mathrm{NaX}$ & 2.36 & - & - & 515.04 & 495.59 & 0.244 & 0.262 \\
$\mathrm{CsX}$ & 2.25 & 1.22 & 30.881 & 412.28 & 384.50 & 0.189 & 0.210 \\
$\mathrm{Cs} /$ mill-X & 2.28 & 1.19 & 30.308 & 425.43 & 389.23 & 0.191 & 0.230 \\
$\mathrm{CsX}-$ mill & 2.25 & 1.29 & 30.812 & 179.04 & 155.97 & 0.077 & 0.113 \\
$\mathrm{CsX}-\mathrm{H}-$ mill-5h & 2.26 & - & 40.301 & 17.66 & 2.58 & 0.001 & 0.043 \\
$\mathrm{CsNO}_{3} /$ ASA & 1.79 & - & 30.993 & 77.71 & 9.62 & 0.004 & 0.235 \\
\hline
\end{tabular}

${ }^{a}$ Determined by XRF. ${ }^{\mathrm{b}}$ Determined by ${ }^{29} \mathrm{Si}$ and ${ }^{27} \mathrm{Al}$ MAS NMR. ${ }^{\mathrm{c}}$ Calculated by the BET method. ${ }^{\mathrm{d}}$ Calculated by the $t$-plot method. 


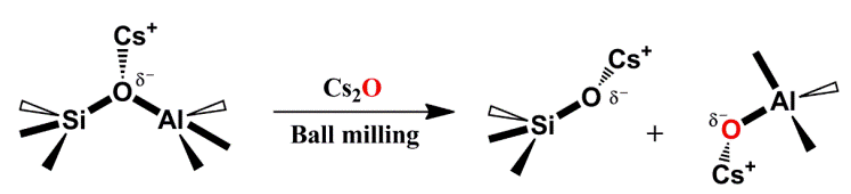

Fig. 4. Simultaneous $\mathrm{Si}-\mathrm{O}-\mathrm{Al}$ and $\mathrm{Cs}_{2} \mathrm{O}$ interaction.

samples are also listed in Table 1. It can be observed that the BET surface area of the cesium ion-exchanged sample (CsX) decreased compared to that of NaX. Decreases are also observed in the micropore volume and total pore volume. This is ascribable to the fact that some cesium ions replaced part of the sodium in NaX. The surface area of CsX-mill was much lower than that of CsX, which means that the ball milling led to partial destruction of the sample. As for Cs/mill-X, both the surface area and the pore volume increased slightly compared to those for CsX. This means that the ball milling did not destroy the NaX structure, but produced smaller zeolite crystals (see SEM image in Fig. 3C). As expected, the BET surface area of Cs/mill-X was much larger than that of CsX-mill because the properties of Cs/mill-X are similar to those of CsX. It is also found that there were almost no micropores on $\mathrm{CsX}-\mathrm{H}-$-mill-5h and $\mathrm{CsNO}_{3} / \mathrm{ASA}$.

It is obvious that the effects of ball milling on $\mathrm{NaX}$ and on CsX were significantly different. For CsX, because the sample was Cs ion-exchanged and calcined before ball milling, the structure destruction might be caused by the combination of ball milling and $\mathrm{Cs}_{2} \mathrm{O}$ (which was detected by XRD, as shown in Fig. 2) on the zeolite framework. In this case, the cleavage of $\mathrm{Si}-\mathrm{O}-\mathrm{Al}$ bonds and the interaction of $\mathrm{Cs}_{2} \mathrm{O}$ with these broken bonds must take place simultaneously and may generate new basic sites that differ from the conventional basic sites of $\mathrm{Si}-\mathrm{O}(\mathrm{Cs})-\mathrm{Al}$ by the $\mathrm{Cs}$ that is ion-exchanged with the bridging $\mathrm{OH}$. A schematic illustration of this mechanism is shown in Fig. 4.

(a)

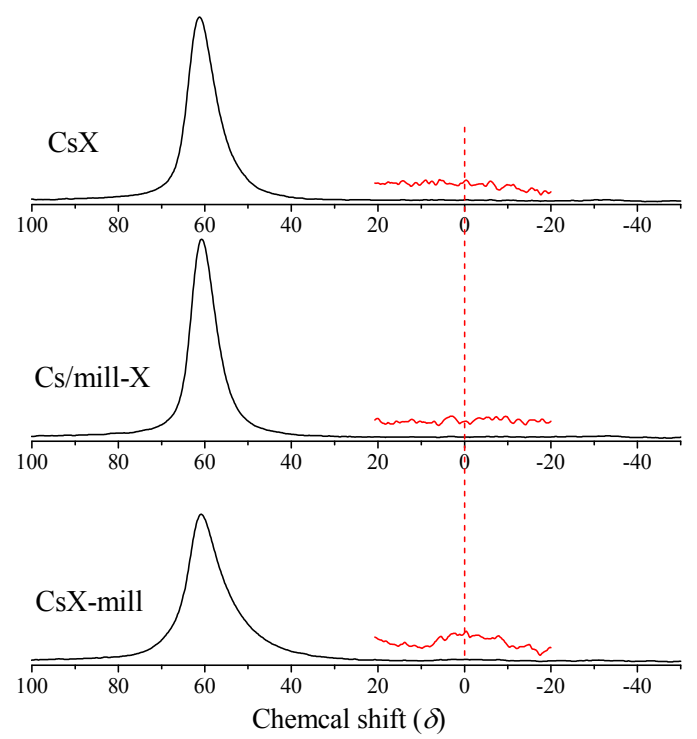

To confirm this hypothesis, the framework atom coordination states, Cs distribution, and chemical states were further studied by solid-state NMR, EDX, and XPS characterizations, as described in the following section.

\subsection{4. ${ }^{29}$ Si MAS and ${ }^{27}$ Al MAS NMR spectra}

Solid-state ${ }^{27} \mathrm{Al}$ and ${ }^{29} \mathrm{Si}$ MAS NMR spectra were employed to investigate the local atomic coordination environments of the three samples. As shown in Fig. 5(a), for all three samples in the ${ }^{27} \mathrm{Al}$ MAS NMR one dominant peak centered at $\delta=60$ exists, which corresponds to tetrahedral coordinated aluminum species. No peak centered at $0 \delta$ is observed for CsX or Cs/mill-X, which indicates that all the $\mathrm{Al}$ atoms of both samples have been incorporated in the framework. However, a weak peak at $\delta=0$ is observed for CsX-mill, which is attributed to extra-framework $\mathrm{Al}$ species in the octahedral coordination state. Meanwhile, the peak of the tetrahedral-framework $\mathrm{Al}$ of CsX-mill is slightly broadened owing to changes in its local chemical environment resulting from the ball milling treatment compared to that of CsX. As shown in Fig. 5(b), the ${ }^{29} \mathrm{Si} \mathrm{MAS}$ NMR spectra of all three samples present a dominant peak at $\delta$ $=-84$ and four overlapped peaks at approximately $\delta=-89$, $-94,-98$, and -102 belonging to $\mathrm{Si}(4 \mathrm{Al}), \mathrm{Si}(3 \mathrm{Al}), \mathrm{Si}(2 \mathrm{Al})$, $\mathrm{Si}(1 \mathrm{Al})$, and $\mathrm{Si}(0 \mathrm{Al})$, respectively. A small amount of desilication occurs in Cs/mill-X compared to that in CsX, which is implied by a lower $\mathrm{Si} / \mathrm{Al}$ ratio, as listed in Table 1 . Notably, there is also a signal centered at approximately $\delta=-81$ in the spectrum of CsX-mill, which could be assigned to $\mathrm{Si}(x \mathrm{Al})(\mathrm{OCs})_{y}$ species formed by destruction. Combined with the corresponding ${ }^{27} \mathrm{Al}$ MAS NMR spectrum, the Si-O-Al cleavage and structure destruction by ball milling are proven.

\subsubsection{XPS spectra of Cs $3 d_{5 / 2}$}

Further study was focused on the distribution and chemical

(b)

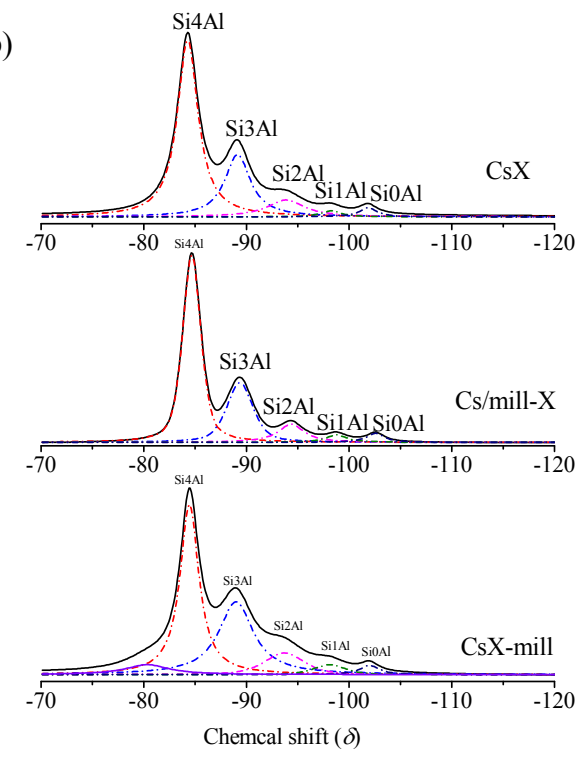

Fig. 5. ${ }^{27} \mathrm{Al}(\mathrm{a})$ and ${ }^{29} \mathrm{Si}(\mathrm{b}) \mathrm{MAS}$ NMR spectra of different samples. 


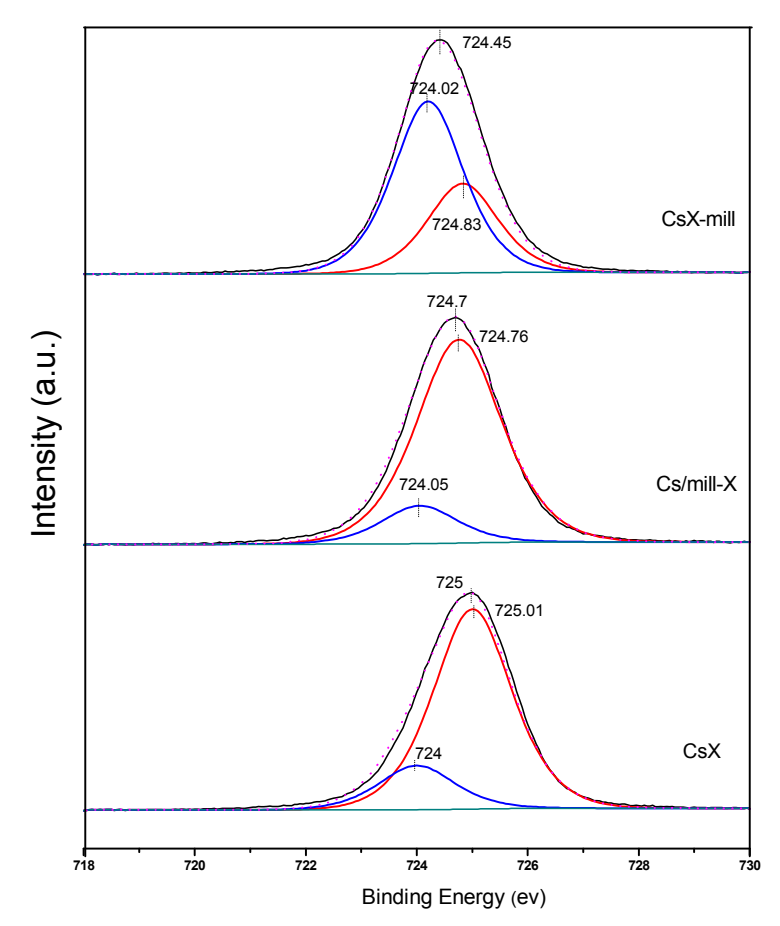

Fig. 6. XPS spectra of Cs $3 d_{5 / 2}$ of Cs-modification samples.

state of the Cs species on the zeolite surface, and XPS was employed. Figure 6 displays the XPS spectra in the Cs $3 d_{5 / 2}$ region for Cs-modified samples. It can be observed that Cs $3 d_{5 / 2}$ BEs decrease from $725.0 \mathrm{eV}$ for CsX to $724.45 \mathrm{eV}$ for CsX-mill. Meanwhile, each main peak corresponding to cesium can be fitted into two sub-peaks, which implies that cesium exists in two chemical states. According to previous research [20] and the NIST XPS Database [21], the signal of Cs $3 d_{5 / 2}$ near $724 \mathrm{eV}$ belongs to the cesium ion, which balances the negative charge of the zeolite skeleton, and the other signal near $725 \mathrm{eV}$ can be assigned to $\mathrm{Cs}_{2} \mathrm{O}$. From Fig. 6, it was found that the proportion of cesium ions of CsX-mill increased compared to that of CsX and Cs/mill-X (Table S1). CsX-mill comes from the ball milling of CsX. Ball milling leads to an increase in the proportion of cesium ions on the zeolites, which can be attributed to the sim- ultaneous framework destruction and solid-state exchange between $\mathrm{Cs}_{2} \mathrm{O}$ and the broken bonds. The cesium ion is an active acidic site of the reaction, which could stabilize the benzene ring of the toluene. Therefore, the number of active sites increased with increasing fraction of cesium ions on the zeolites. Because the proportion of $\mathrm{Cs}_{2} \mathrm{O}$ decreased correspondingly, the base strength declined, which is in accordance with the results of $\mathrm{CO}_{2}$-TPD (discussed in the following section). The total weight percentage of cesium on the surface of all samples is listed in Table S1. It can be seen that there was little change in the total content of cesium on the surface of all three samples.

Furthermore, representative elemental maps of the cesium and sodium distribution of Cs-modification samples are shown in Fig. S3. The figure shows that the cesium distribution on the surface of the CsX-mill sample is more uniform than that of CsX and Cs/mill-X.

These results, combined with the evidence from the NMR characterization, support the proposed mechanism of structure destruction and Cs species redistribution during the ball milling of Cs exchanged zeolite.

\subsection{6. $\mathrm{NH}_{3}$ - $\mathrm{TPD}$ and $\mathrm{CO}_{2}-\mathrm{TPD}$}

To confirm the alteration of the acidity and alkalinity of the zeolite resulting from ball milling, $\mathrm{NH}_{3}$ and $\mathrm{CO}_{2}$ adsorption measurements were performed. The results are shown in Fig. 7. As shown in Fig. 7(a), both CsX and Cs/mill-X exhibit one major $\mathrm{NH}_{3}$ desorption peak centered at $150{ }^{\circ} \mathrm{C}$. The temperature of the $\mathrm{NH}_{3}$ desorption peak corresponds to the strength of the acidic sites [22,23], so the peak centered at $150{ }^{\circ} \mathrm{C}$ corresponds to weak acidic sites. The number of acidic sites of $\mathrm{CsX}$ is slightly higher than that of $\mathrm{Cs} /$ mill-X according to the peak area. However, there was no desorption peak on the CsX-mill profile, which indicates that no acidity could be detected by $\mathrm{NH}_{3}$ chemisorption technologies on the CsX-mill sample.

Figure 7 (b) shows the $\mathrm{CO}_{2}$-TPD profiles of all Cs-modified samples. It can be observed that the peak area of $\mathrm{CO}_{2}$ desorption of $\mathrm{Cs} /$ mill-X increased slightly compared to that of CsX. This indicates that the ball milling of NaX slightly increased the number of exchangeable sites for the Cs species. However, the
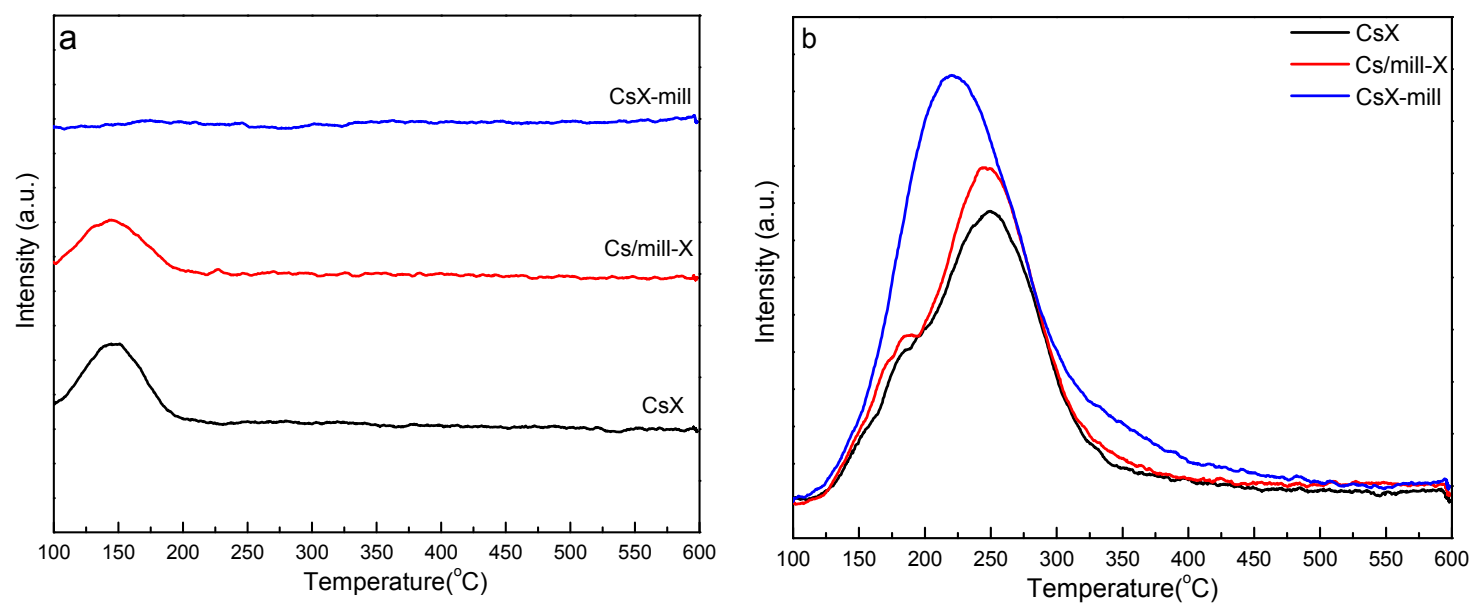

Fig. 7. $\mathrm{NH}_{3}-\mathrm{TPD}(\mathrm{a})$ and $\mathrm{CO}_{2}$-TPD (b) profiles of Cs-modification samples. 
number of basic sites of CsX-mill increased considerably. The center of the $\mathrm{CO}_{2}$ desorption peak of CsX-mill moved to a slightly lower temperature compared to that of CsX, indicating that the base strength of CsX-mill decreased slightly. According to the Beran and Dubsky's CNDO calculations [24], the ionicity of the $\mathrm{Si}(\mathrm{Al})-\mathrm{O}$ bonds in the zeolite framework is higher than that in amorphous silica alumina. Moreover, the BE data of $01 \mathrm{~s}$ from the NIST XPS Database also show that the basicity of the zeolite framework oxygen is weaker than that of the lattice oxygen of $\mathrm{Cs}_{2} \mathrm{O}$. Therefore, we propose that the decreased base strength and increased number of basic sites on CsX-mill can be attributed to the fact that the particles of $\mathrm{Cs}_{2} \mathrm{O}$ on the zeolites interact with the zeolites again during the process of ball milling, which contributes to the redispersion of the Cs species and generates some weaker basic sites, such as $\mathrm{Si}-\mathrm{O}-\mathrm{Cs}$ and Al-0-Cs (Fig. 4). The detailed amounts of acidic and basic sites for each catalyst are listed in Table S2. From the results of $\mathrm{CO}_{2}$-TPD, it could be inferred that the basic centers on CsX-mill had a different nature from those on CsX and Cs/mill-X, which is consistent with the proposed generation of new basic sites by broken $\mathrm{Si}-\mathrm{O}-\mathrm{Al}$ bonds and $\mathrm{Cs}_{2} \mathrm{O}$ redistribution.

\subsubsection{Pyridine adsorption FT-IR spectroscopy}

The acid types of all Cs-modification samples were investigated by pyridine (Py) adsorption FT-IR spectroscopy. The experiments were performed at $150{ }^{\circ} \mathrm{C}$ and $350{ }^{\circ} \mathrm{C}$. The obtained spectra are shown in Fig. 8. The IR adsorption peak at $1450 \mathrm{~cm}^{-1}$ (or $1540 \mathrm{~cm}^{-1}$ ) can be considered as a Lewis (or Brönsted) acidic site of zeolites [25,26]. The results at $150{ }^{\circ} \mathrm{C}$ indicate that no Brönsted acidic sites could be found for those catalysts. Three adsorption peaks of Py centered at 1580, 1485, and $1440 \mathrm{~cm}^{-1}$ appear in Fig. 8(a). It has been reported that the ring stretching modes of physically adsorbed Py are clearly observed at 1581 (mode 8b), 1485 (mode 19a), and $1439 \mathrm{~cm}^{-1}$ (mode 19b) [27]. Combined with the $v(\mathrm{CH})$ stretching characteristics in the range of $3100-3000 \mathrm{~cm}^{-1}$ (inset in Fig. 8(a)), it was confirmed that physically adsorbed Py was not fully desorbed at $150{ }^{\circ} \mathrm{C}$ in our experiment. However, it has also been reported that the bands at $1441 \mathrm{~cm}^{-1}$ originate from cations in the supercage of faujasite, which could exhibit the properties of a Lewis acid [28]. Therefore, the presence of Lewis acidic sites on our Cs modification samples cannot be excluded. With the evacuation temperature increasing from $150{ }^{\circ} \mathrm{C}$ to $350{ }^{\circ} \mathrm{C}$, the intensities of all peaks decreased dramatically and almost disappeared, as shown in Fig. 8(b). Two aspects can be confirmed: first, physically adsorbed Py can be absolutely desorbed at 350 ${ }^{\circ} \mathrm{C}$; second, if any Lewis acidic sites exist on our sample, they must be not strong.

\subsection{Catalytic performance}

The catalytic reaction results of the side-chain alkylation of toluene with methanol are displayed in Fig. 9. As shown in Fig. 9(a), CsX-mill exhibits higher toluene conversion $\left(C_{\mathrm{T}}\right)$ compared to those of other samples, and the initial $C_{\mathrm{T}}$ of CsX-mill was the highest. However, the initial methanol conversion (Fig. 9(b)) of CsX-mill was not the highest among the three catalysts. Meanwhile, a significant difference appeared at the early stage of the reaction. Although the $C_{\mathrm{T}}$ value of $\mathrm{Cs} /$ mill-X was slightly higher than that of CsX owing to the larger number of basic centers on $\mathrm{Cs} / \mathrm{mill}-\mathrm{X}$, as confirmed by $\mathrm{CO}_{2}$-TPD, the $C_{\mathrm{T}}$ value of these two catalysts shows a similar variation with TOS, with both increasing to a maximum and then decreasing. This indicates the existence of an induction period for the side-chain alkylation of toluene with methanol. However, this induction phenomenon disappears for the CsX-mill sample. The selectivity of the side-chain alkylation products (styrene plus ethylbenzene) as a function of time on stream is shown in Fig. 9(c). It can be seen that the selectivity of styrene plus ethylbenzene $\left(S_{\mathrm{ST}+\mathrm{EB}}\right)$ for CsX-mill is the highest among the three catalysts. CsX and Cs/mill-X have a similar product selectivity of side-chain alkylation. The ratio of styrene and ethylbenzene as a function of time on stream is shown in Fig. S4. It can be seen that CsX-mill shows a higher ethylbenzene selectivity. The variation of the CO content in the effluent products with the time on stream is shown in Fig. 9(d). It can be observed that the CO selectivity in the initial products of the catalysts varies greatly. Subsequently, their levels of CO content converge. The CO formation can be well correlated with methanol conversion and even toluene conversion. For CsX and Cs/mill-X, the initial CO
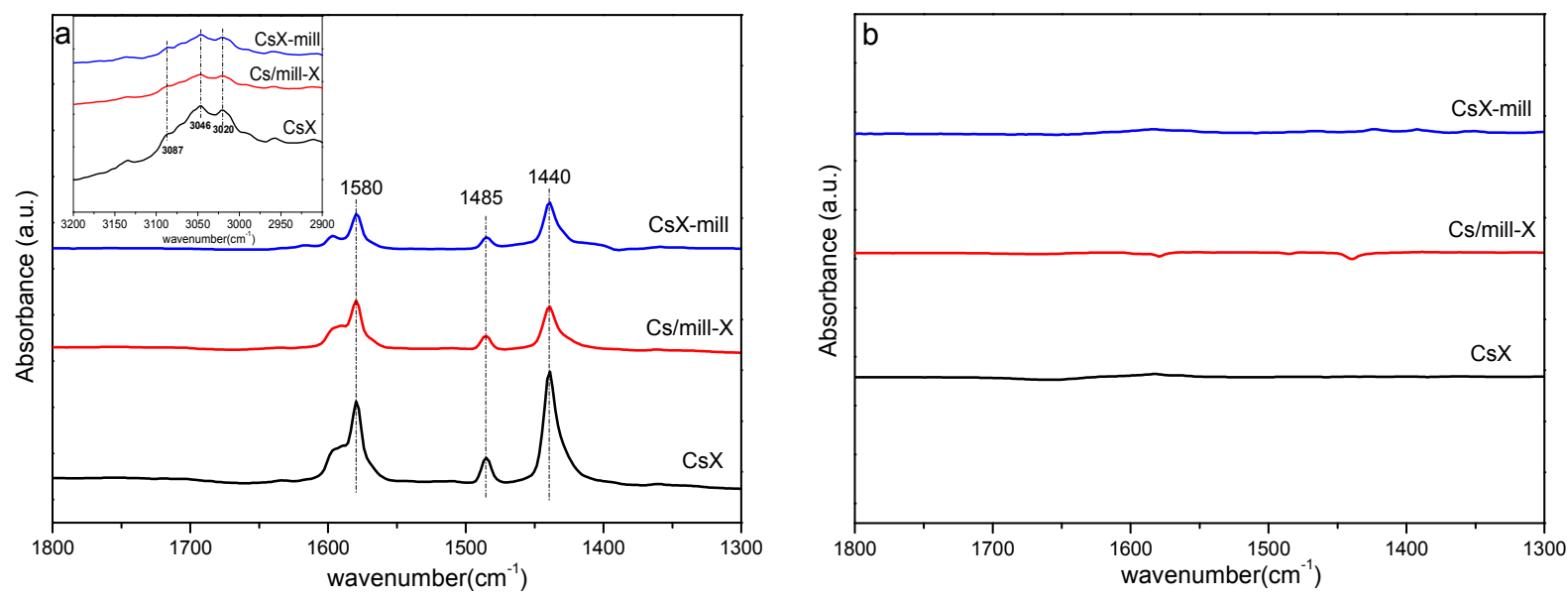

Fig. 8. FT-IR spectra of Py adsorbed on all Cs-modification samples at $150^{\circ} \mathrm{C}$ (a) and $350^{\circ} \mathrm{C}$ (b). 

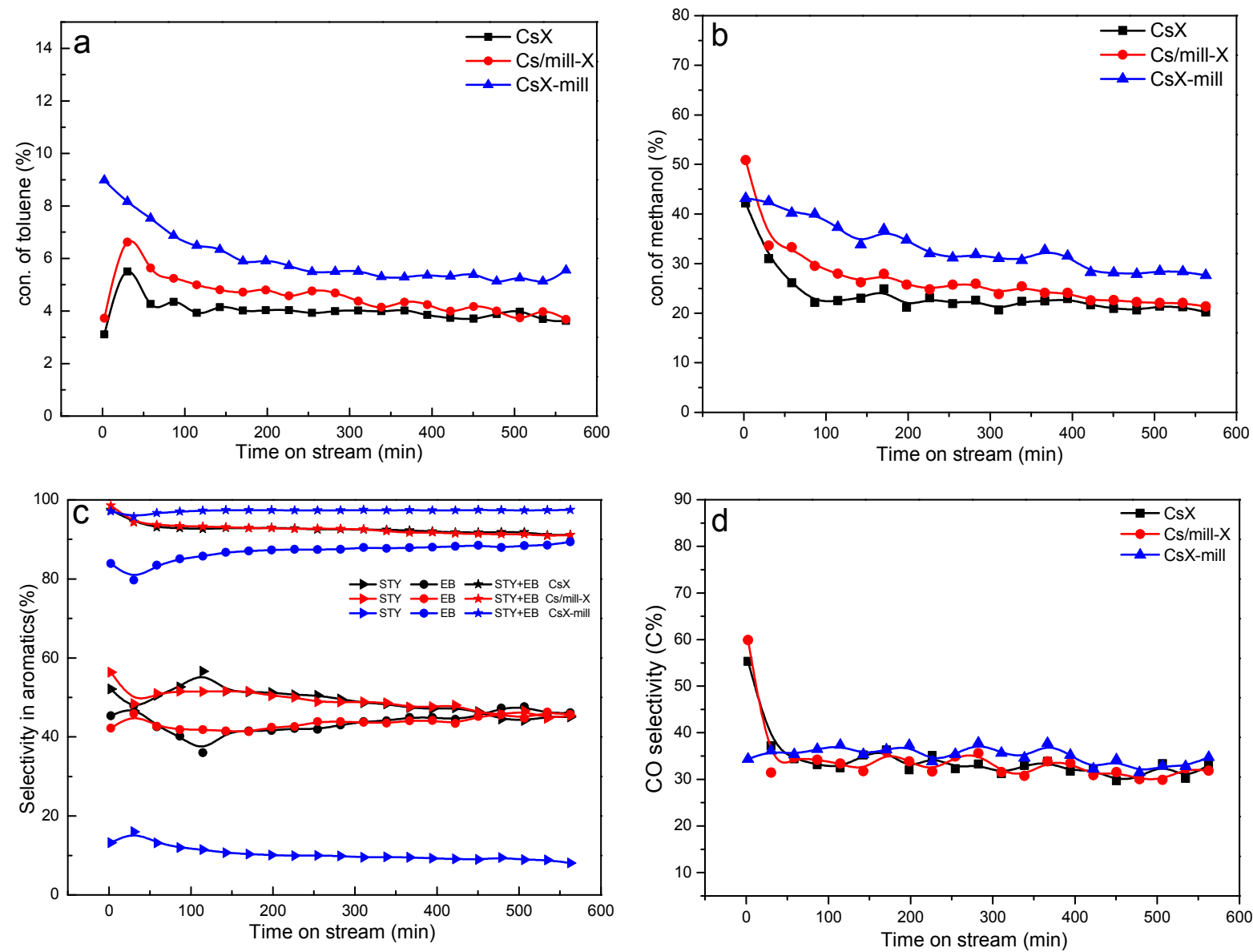

Fig. 9. Toluene conversion (a), methanol conversion (b), selectivity of side-chain products in aromatics (c), and CO selectivity (C\%) (d) as a function of time on stream for Cs-modification samples. Reaction conditions: $425^{\circ} \mathrm{C}, \mathrm{WHSV}=2 \mathrm{~h}^{-1}, n$ (toluene) $/ n$ (methanol) $=1$.

fraction is very high, which is accompanied by high methanol conversion but lower toluene conversion. However, for CsX-mill, a relatively lower initial CO fraction and methanol conversion is observed, which is accompanied by high toluene conversion.

Figure 10 displays the average $C_{\mathrm{T}}, S_{\mathrm{ST}}$, and $S_{\mathrm{ST}+\mathrm{EB}}$ with $Y_{\mathrm{ST}+\mathrm{EB}}$ over $9 \mathrm{~h}$ for different samples. It can be observed that CsX-mill has the highest $C_{\mathrm{T}}(5.55 \%)$ and the highest $Y_{\mathrm{ST}+\mathrm{EB}}(5.41 \%)$.

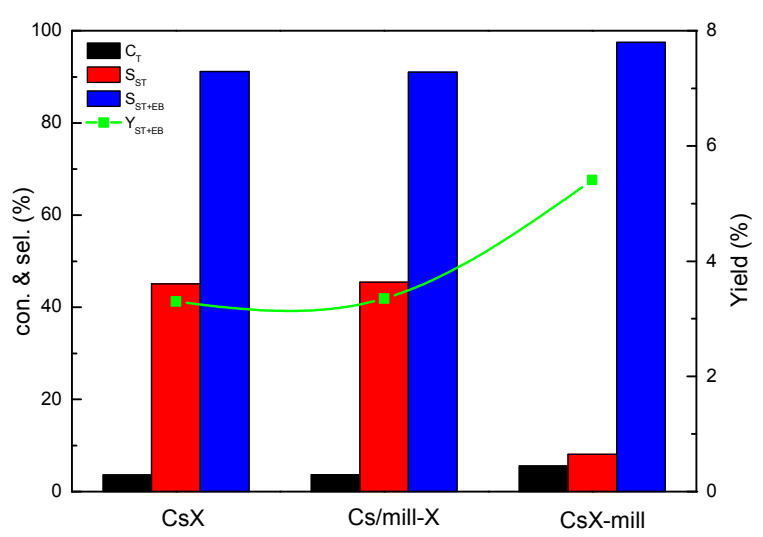

Fig. 10. Catalytic performance of different catalysts at $425^{\circ} \mathrm{C}$; WHSV $=$ $2 \mathrm{~h}^{-1}$; the mole ratio of the reactants is $1: 1$.
However, the styrene selectivity of CsX-mill is much lower than that of CsX. CsX and Cs/mill-X have similar reactivities. The distributions of various gas products over $9 \mathrm{~h}$ are listed in Table S3.

Because ball milling can increase the basicity (positive effect) and decrease the micropore volume (negative effect), ball milling experiments for various time periods were also per-

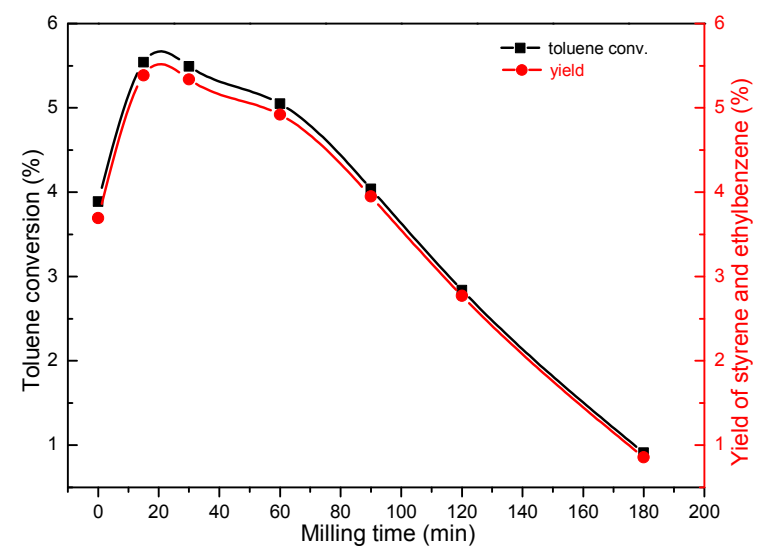

Fig. 11. Toluene conversion and yield of styrene and ethylbenzene as a function of milling time of the catalysts. 
formed to elucidate these two competitive effects. The reaction results of the resultant materials are shown in Fig. 11. The optimum milling time was found to be approximately $25 \mathrm{~min}$. The micropore volumes of this series of catalysts are listed in Table S4.

For comparison, the reaction was also tested on CsX-mill-5h, $\mathrm{CsNO}_{3} / \mathrm{ASA}$, and other materials impregnated with cesium hydroxide solution. Unfortunately, there was almost no side-chain alkylation activity on these samples. The specific reaction results are shown in Fig. 12 and Table 2.

\subsection{Catalytic mechanism}

The mechanism for toluene side-chain methylation with methanol for alkali-metal-modified zeolites has been discussed by many researchers $[6,29,30]$. The framework oxygen is considered as basic sites, on which the methyl $\mathrm{C}-\mathrm{H}$ bonds of toluene polarizes and methanol dehydrogenates to formaldehyde, which, as an active intermediate, attacks the methyl group of toluene to form 2-phenylethanol. This process could produce styrene and water through an intramolecular dehydration step. The intermediate formaldehyde could be further decomposed into $\mathrm{CO}$ and $\mathrm{H}_{2}$ at strong basic sites. Ethylbenzene is mainly produced by transfer hydrogenation between styrene and methanol, and a small amount of it is formed by hydrogenation of styrene with hydrogen [26,31]. Besides, $\mathrm{Cs}_{2} \mathrm{O}$ introduced into the zeolites could promote the base properties of $\mathrm{O}^{\delta \text { - }}$ in the zeolite framework by the electron-donating function of alkali oxides [26,32], which subsequently contribute to the decomposition of methanol/formaldehyde. As mentioned above, the Cs species on CsX and Cs/mill-X exists mainly in the form of $\mathrm{Cs}_{2} \mathrm{O}$. The phenomena observed at the initial stage of the reaction on these two catalysts could be explained by the fact that a large amount of methanol is decomposed into $\mathrm{CO}$ owing to the strong base properties of zeolites, leading to a reduction in the amount of activated methanol reacting with toluene. Besides, the stable adsorption of toluene on the catalysts also requires time. With the prolongation of the reaction time, the ability to decompose methanol on CsX and Cs/mill-X decreases and the amount of

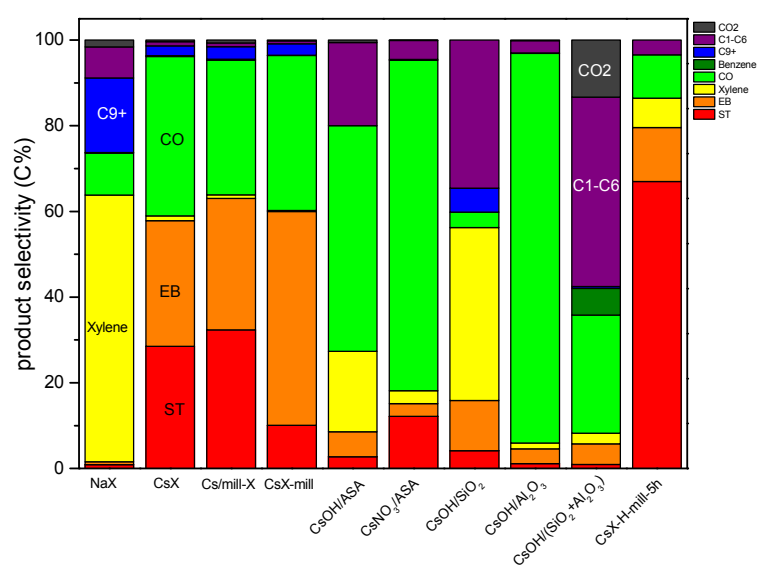

Fig. 12. Product selectivity (C\%) of different catalysts at $425^{\circ} \mathrm{C}$; WHSV $=2 \mathrm{~h}^{-1}$; the mole ratio of the reactants is $1: 1$. The data were collected at 31 min time on stream.
Table 2

Side-chain alkylation of toluene with methanol on different catalysts.

\begin{tabular}{lccc}
\hline Catalyst & $\begin{array}{c}\text { Toluene } \\
\text { conversion } \\
(\%)\end{array}$ & $\begin{array}{c}\text { Methanol } \\
\text { conversion } \\
(\%)\end{array}$ & $\begin{array}{c}\text { Decomposition } \\
\text { ratio of methanol } \\
\left(\mathrm{CO}+\mathrm{CO}_{2}\right)^{\mathrm{a}, \mathrm{b}}(\%)\end{array}$ \\
\hline $\mathrm{NaX}$ & 8.18 & 27.00 & 10.14 \\
$\mathrm{CsX}$ & 5.51 & 30.99 & 25.07 \\
$\mathrm{Cs} / \mathrm{mill}-\mathrm{X}$ & 6.62 & 33.63 & 25.97 \\
$\mathrm{CsX}-\mathrm{mill}$ & 8.16 & 42.51 & 34.23 \\
$\mathrm{CsOH} / \mathrm{ASA}$ & 0.04 & 1.58 & 1.11 \\
$\mathrm{CsNO} / \mathrm{ASA}$ & 0.15 & 10.51 & 9.67 \\
$\mathrm{CsOH} / \mathrm{SiO}_{2}$ & 0.04 & 0.40 & 0.03 \\
$\mathrm{CsOH} / \mathrm{Al}_{2} \mathrm{O}_{3}$ & 0.10 & 30.99 & 29.80 \\
$\mathrm{CsOH} /\left(\mathrm{SiO}_{2}+\mathrm{Al}_{2} \mathrm{O}_{3}\right)$ & 0.08 & 2.85 & 0.70 \\
$\mathrm{CsX}-\mathrm{H}-\mathrm{mill}^{-5 h}$ & 0.32 & 1.22 & 0.51 \\
\hline
\end{tabular}

a Data collected at 31 min time on stream.

${ }^{\mathrm{b}}$ Calculated as $\left(\mathrm{CO}_{\text {out }}+\mathrm{CO}_{2 \text { out }}\right) / \mathrm{Methanol}_{\text {in }} \times 100 \%$.

activated methanol reacting with toluene increases, inducing increased toluene conversion. The subsequent reduction in toluene conversion is due to the slight deactivation of the catalyst. However, the proportion of Cs in the ionic state is higher on CsX-mill, which could lead to rapid adsorption of toluene. Besides, the decrease in the proportion of $\mathrm{Cs}_{2} \mathrm{O}$ means that methanol does not decompose into $\mathrm{CO}$ too much, but reaches the active site directly and reacts with toluene, thus explaining why the conversion of toluene reaches the maximum immediately at the initial stage of the reaction. At the later stage of the reaction, the relative content of $\mathrm{CO}$ on the three catalysts is very similar, but the ratio of ST/EB is different (shown in Fig. S3). This contradicts previous literature that reports that a higher content of carbon monoxide in the outlet products corresponds to a lower ratio of styrene to ethylbenzene [9,31].

From the reaction results on $\mathrm{CsX}-\mathrm{H}-\mathrm{mill}-5 \mathrm{~h}$ and $\mathrm{CsNO}_{3} / \mathrm{ASA}$, as well as the experiments with various ball milling times, microporosity seems to play an important role in side-chain alkylation. Recently, the necessity of microporosity was confirmed [33]. Although it has been previously reported that siloxy sites linked to defects in zeolites could be basic centers also for some base-catalyzed reactions [34], these basic centers could not act effectively alone for side-chain methylation without microporosity according to our comparative experiments. Based on the characterization results and reports in the literature, we propose that the different reaction phenomena and improved catalytic activity can be attributed to the presence of new basic centers (Fig. 4). However, this promotion could occur only in the presence of micropores.

\section{Conclusions}

Ball milling on CsX was demonstrated to be an effective physical method to improve the reactivity of side-chain methylation. The promotional effect is attributed to two main factors: first, the number of basic sites on CsX-mill increases considerably after ball milling; second, more active sites for side-chain methylation of toluene are exposed due to ball milling on CsX. Surface $\mathrm{Cs}_{2} \mathrm{O}$ particles further interact with zeolites during the ball milling process, generating new basic sites, such 


\section{Graphical Abstract}

Chin. J. Catal., 2020, 41: 1268-1278 doi: 10.1016/S1872-2067(20)63567-7

Role of ball milling during Cs/X catalyst preparation and effects on catalytic performance in side-chain alkylation of toluene with methanol

Qijun Yu, Jinzhe Li, Changcheng Wei, Shu Zeng, Shutao Xu, Zhongmin Liu*

Dalian Institute of Chemical Physics, Chinese Academy of Sciences; University of Chinese Academy of Sciences

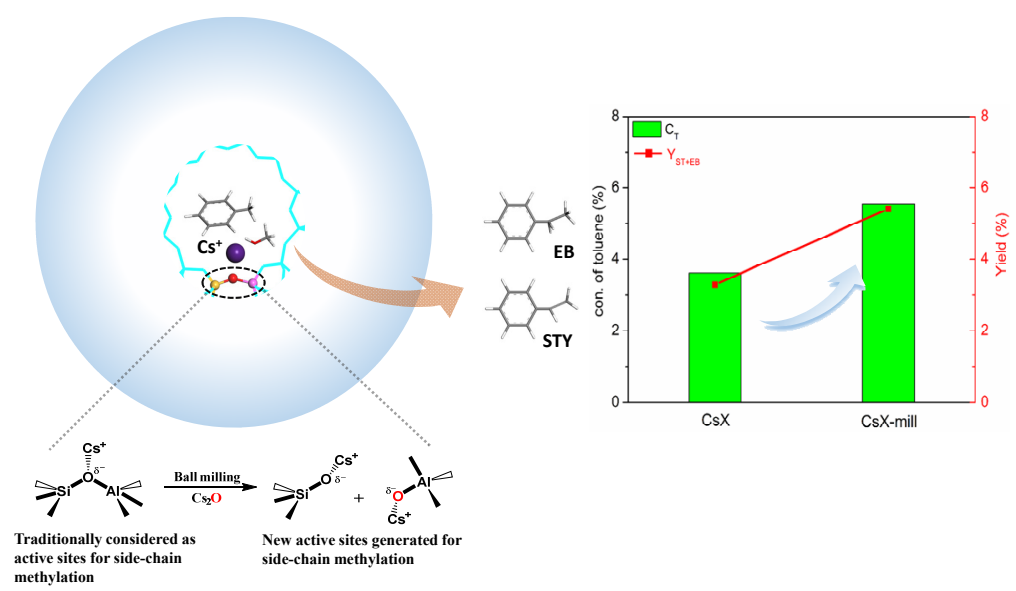

New active sites, such as $\mathrm{Si}-\mathrm{O}-\mathrm{Cs}$ and $\mathrm{Al}-\mathrm{O}-\mathrm{Cs}$, are produced by the interaction between $\mathrm{Cs}_{2} \mathrm{O}$ species on zeolites and the framework of zeolites during ball milling, which favor the side-chain methylation reaction.

as $\mathrm{Si}-\mathrm{O}-\mathrm{Cs}$ and $\mathrm{Al}-\mathrm{O}-\mathrm{Cs}$, and resulting in more uniform cesium distribution. These sites might help to improve reactivity when zeolite micropores still exist. These findings offer a new way to increase the alkalinity of zeolites besides loading more Cs substances on zeolites.

\section{References}

[1] I. N. Sidorenko, P. N. Galich, V. S. Gutirya, Dokl. Akad. Nauk SSSR, 1967, 173, 132-134.

[2] T. Yashima, K. Sato, T. Hayasaka, N. Hara, J. Catal., 1972, 26, 303-312.

[3] A. Borgna, S. Magni, J. Sepúlveda, C. L. Padró, C. R. Apesteguía, Catal. Lett., 2005, 102, 15-21.

[4] M. Lasperas, H.e. Cambon, D. Brunel, I. Rodriguez, P. Geneste, Microporous Mater., 1996, 7, 61-72.

[5] H. Han, M. Liu, F. Ding, Y. Wang, X. Guo, C. Song, Ind. Eng. Chem. Res., 2016, 55, 1849-1858.

[6] H. Itoh, A. Miyamoto, Y. Murakami, J. Catal., 1980, 64, 284-294.

[7] A. Borgna, J. Sepúlveda, S. I. Magni, C. R. Apesteguía, Appl. Catal. A, 2004, 276, 207-215.

[8] H. Hattori, W. O. Alabi, B. R. Jermy, A. M. Aitani, S. S. Al-Khattaf, Catal. Lett., 2013, 143, 1025-1029.

[9] H. Han, M. Liu, X. Nie, F. Ding, Y. Wang, J. Li, X. Guo, C. Song, Microporous Mesoporous Mater., 2016, 234, 61-72.

[10] J. H. Xie, S. Kaliaguine, Appl. Catal. A, 1997, 148, 415-423.

[11] T. Wakihara, R. Ichikawa, J. Tatami, A. Endo, K. Yoshida, Y. Sasaki, K. Komeya, T. Meguro, Cryst. Growth Des., 2011, 11, 955-958.

[12] T. Wakihara, K. Sato, S. Inagaki, J. Tatami, K. Komeya, T. Meguro, Y. Kubota, ACS Appl. Mater. Interfaces, 2010, 2, 2715-2718.

[13] T. Wakihara, A. Ihara, S. Inagaki, J. Tatami, K. Sato, K. Komeya, T.
Meguro, Y. Kubota, A. Nakahira, Cryst. Growth Des., 2011, 11, 5153-5158.

[14] M. Yang, P. Tian, C. Wang, Y. Yuan, Y. Yang, S. Xu, Y. He, Z. Liu, Chem. Commun., 2014, 50, 1845-1847.

[15] T. Wakihara, K. Sato, K. Sato, J. Tatami, S. Kohara, K. Komeya, T. Meguro, J. Ceram. Soc. Jpn., 2012, 120, 341-343.

[16] F. Fan, Z. Feng, G. Li, K. Sun, P. Ying, C. Li, Chem.-Eur. J., 2008, 14, 5125-5129.

[17] E. Diaz, E. Munoz, A. Vega, S. Ordonez, Chemosphere, 2008, 70, 1375-1382.

[18] G. Sethia, R. S. Somani, H. C. Bajaj, Ind. Eng. Chem. Res., 2014, 53, 6807-6814.

[19] D. Verboekend, N. Nuttens, R. Locus, J. Van Aelst, P. Verolme, J. C. Groen, J. Perez-Ramirez, B. F. Sels, Chem. Soc. Rev., 2016, 45, 3331-3352.

[20] G. Ebbinghaus, A. Simon, Chem. Phys., 1979, 43, 117-133.

[21] NIST X-ray Photoelectron Spectroscopy Database, http://dx.doi.org/10.18434/T4T88K

[22] Y. Zhao, W. Tan, H. Wu, A. Zhang, M. Liu, G. Li, X. Wang, C. Song, X. Guo, Catal. Today, 2011, 160, 179-183.

[23] W. Tan, M. Liu, Y. Zhao, K. Hou, H. Wu, A. Zhang, H. Liu, Y. Wang, C. Song, X. Guo, Microporous Mesoporous Mater., 2014, 196, 18-30.

[24] S. Beran, J. Dubsky, J. Phys. Chem., 1979, 83, 2538-2544.

[25] J. Jiang, G. Lu, C. Miao, X. Wu, W. Wu, Q. Sun, Microporous Mesoporous Mater., 2013, 167, 213-220.

[26] W. O. Alabi, B. B. Tope, R. B. Jermy, A. M. Aitani, H. Hattori, S. S. Al-Khattaf, Catal. Today, 2014, 226, 117-123.

[27] R. Buzzoni, S. Bordiga, G. Ricchiardi, C. Lamberti, A. Zecchina, Langmuir, 1996, 12, 930-940.

[28] A. Auroux, M. Huang, S. Kaliaguine, Langmuir, 1996, 12, 4803-4807.

[29] A. E. Palomares, G. Eder-Mirth, M. Rep, J. A. Lercher, J. Catal., 1998, 
180, 56-65.

[30] Y. Wang, M. Zhu, L. Kang, B. Dai, Microporous Mesoporous Mater., 2014, 196, 129-135.

[31] P. Li, Q. Han, X. Zhang, Y. Yuan, Y. Zhang, H. Guo, L. Xu, L. Xu, Catal. Sci. Technol., 2018, 8, 3346-3356.
[32] P. Li, Q. Han, X. Zhang, Y. Yuan, Y. Zhang, L. Xu, H. Guo, L. Xu, RSC Adv., 2019, 9, 13234-13242.

[33] H. Lee, S. Lee, R. Ryoo, M. Choi, J. Catal., 2019, 373, 25-36.

[34] T. C. Keller, E. G. Rodrigues, J. Perez-Ramirez, ChemSusChem, 2014, 7, 1729-1738.

\title{
球磨在制备 $\mathrm{Cs} / \mathrm{X}$ 型催化剂中的作用以及对甲苯甲醇侧链烷基化反应的影响
}

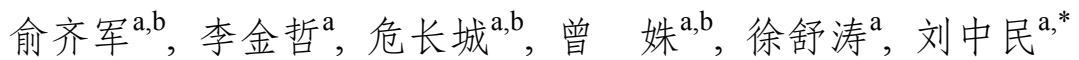 \\ ${ }^{\mathrm{a}}$ 中国科学院大连化学物理研究所, 中国科学院洁净能源创新研究院, 甲醇制烯烃国家工程实验室, 辽宁大连116023 \\ 中国科学院大学, 北京 100049
}

\begin{abstract}
摘要: 苯乙烯是重要的化工中间体, 可以用来生产聚苯乙烯以及其他多聚物化学品. 工业上苯乙烯主要通过苯和乙烯烷基 化生成乙苯, 再将乙苯脱氢制得. 该方法存在能耗高、工艺流程复杂、生产成本高等问题. 甲苯与甲醇在碱性分子篮上可 以发生侧链烷基化反应直接生成苯乙烯, 在各种碱性分子篮上中, Cs离子交换的 X型分子篎催化剂(CsX)表现出较为突出的 催化性能. 尽管如此, 低的甲苯转化率和苯乙烯选择性仍然是限制甲苯甲醇侧链烷基化工艺在工业上应用的主要因素. 为 了进一步提高甲苯甲醇侧链烷基化反应的催化性能, 向 CsX催化剂中添加其他化合物或助剂的化学改性方法被广泛研究.

本文采用一种物理方法一球磨法对 $\mathrm{CsX}$ 进行改性, 并对比了 $13 \mathrm{X}$ 分子篮在球磨前和球磨后担载Cs对甲醇甲苯侧链烷基 化反应的影响. 研究发现, $\mathrm{CsX}$ 分子篮在经过球磨之后, 其催化性能大幅提高. 通过各种表征手段进一步阐释了球磨法在 分子篎改性过程中的作用机理. $\mathrm{CO}_{2}$-TPD结果表明, $\mathrm{CsX}$ 在球磨之后碱量增加而碱强度降低. XPS结果显示, CsX-mill上Cs 元素主要以离子型的Cs离子形式存在, 而 CsX上的Cs元素主要以氧化物形式存在. Cs阳离子是路易斯酸中心, 可以与甲苯 的苯环发生作用, 从而吸附稳定甲苯. 离子型Cs比例的增加意味着增加了活性路易斯酸中心. ${ }^{27} \mathrm{Al}$ 和 ${ }^{29} \mathrm{Si} \mathrm{MAS} N \mathrm{NR}$ 结果表 明, CsX经过球磨之后, $\mathrm{Si}$ 和Al的配位环境也产生了些许变化, CsX-mill上有非骨架铝出现. 综上, 我们认为催化效果的显著 差异归因于在球磨过程中分子篮上的 $\mathrm{Cs}_{2} \mathrm{O}$ 与分子篮载体发生了强相互作用, 进而改变了催化剂的酸碱性质并形成了 Si-O-Cs和Al-O-Cs等新的碱性中心. 这些新的碱性中心有别于传统的CsX上的碱性中心, 且可能对反应有促进作用. 然而, 长时间球磨会导致催化剂结构彻底坍塌和微孔消失, 这也从侧面证明了微孔在甲苯甲醇侧链烷基化反应中的重要性. 球 磨法的优势在于不必改变CsX催化剂的Cs含量就可以调节催化剂的酸碱性质, 进而提高侧链烷基化反应的催化效果.
\end{abstract}

关键词: X分子篮; 球磨; 离子交换; 甲苯; 甲醇; 侧链烷基化

收稿日期: 2019-11-11. 接受日期: 2019-12-27. 出版日期: 2020-08-05.

*通讯联系人. 电话: (0411)84379998; 传真: (0411)84379038; 电子信箱: liuzm@dicp.ac.cn

基金来源: 国家自然科学基金(21576256).

本文的电子版全文由Elsevier出版社在ScienceDirect上出版(http://www.sciencedirect.com/science/journal/18722067). 